\title{
MODERNCOMBINATIONS DRESSING AND OZONE BAGGING TREATMENT REDUCES THE AMOUNT OF BACTERIA IN GRADE II DIABETICUM
}

\author{
Mardiyono $^{1}$, Djamaluddin Ramlan ${ }^{2}$, M. Choiroel Anwar ${ }^{3}$, Rr. Sri Endang Pujiastuti ${ }^{4}$, Umi Margi Rahayu ${ }^{5}$ \\ Email : muh.mardiyono@gmail.com
}

\begin{abstract}
ABSTRAK
Diabetic ulcers are open sores on the skin layer to the dermis caused by hyperglycemia and neuropathy. Infection is a barrier to the wound healing process, the incidence of infection in wounds with modern treatments of hydrocolloid and hydrogel type dressings is still high. Ozone has high antibactericidal and antimicrobial properties, is able to penetrate bacterial capsid walls and is expected to kill bacteria on the wound surface.

To find the right way to cure diabetic ulcers using a combination of modern methods of dressing and ozonetherapy bagging.

Experimental, non-equivalent control group design pre test, post test, population and infinite sample of 25 respondents. Modern dressing used has antibacterial properties and ozone concentration of 60-100ug / $\mathrm{ml}$ for 15 minutes using a limb bag was carried out until the 13th day with five times the measurement of the number of bacterial colonies using themethod swab and colonicounter. Data processing using a computer system with the General Linear Model. There was an average difference in the number of bacterial colonies between groups $(505.73 \pm$ 172.069 vs $322.21 \pm 132.778, \mathrm{p}=0.0061)$.

A combination of modern dressing and ozonetherapy bagging can reduce the number of bacterial colonies and speed up the healing process of the inflammatory phase II diabetic ulcer so that it can be applied in nursing care for diabetic ulcer patients.
\end{abstract}

Keywords: diabetic ulcer, modern dressing, ozone bagging, wound healing process

1) Poltekkes Kemenkes Semarang

\section{PENDAHULUAN}

Ulkus diabetikum merupakan luka terbuka pada lapisan kulit sampai ke dalam dermis. Komplikasi ini dapat terjadi karena adanya hiperglikemia dan neuropati yang mengakibatkan berbagai perubahan pada kulit dan otot, sehingga terjadi ketidakseimbangan distribusi tekanan pada telapak kaki dan selanjutnya akan mempermudah terjadinya ulkus $^{1}$. Ulkus diabetik di Indonesia merupakan permasalahan yang belum dapat dikelola dengan baik hal ini dibuktikan dengan angka prevalensi terjadinya ulkus diabetik di Indonesia sebesar $15 \%$ dan sering kali berakhir dengan kecatatan dan kematian ${ }^{2}$. Pada pasien ulkus diabetikum, 50\% akan mengalami infeksi akibat adanya glukosa darah yang tinggi karena merupakan media pertumbuhan bakteri yang subur ${ }^{3}$. Bakteri yang terdapat pada ulkus merupakan gabungan antara bakteri aerob dan anaerob, bakteri yang paling sering menyebabkan infeksi adalah aerobic gram-positif cocci (khususnya $\mathrm{S}$ aureus), terkadang juga disebabkan oleh bakteri gram negative seperti Pseudomonas aeuruginosa Enterococcus ${ }^{4}$. Pasien DM yang disertai komplikasi ulkus diabetikum, memerlukan penatalaksanaan holistik pada luka ulkus diabetes salah satunya kontrol luka dan kontrol infeksi ${ }^{5}$.

Kontrol luka merupakan bentuk upaya perawatan luka berupa tindakan pembuangan jaringan terinfeksi dan nekrotis secara teratur ${ }^{6}$. Prinsip perawatan luka adalah menciptakan kondisi optimal/kondusif ${ }^{7}$ dengan menggunakan modern dressing, menciptakan kondisi lembab sehingga mempercepat penyembuhan luka ${ }^{7}$. Kontrol infeksi pada pasien dengan ulkus diabetikum dengan memberikan antibiotik spectrum luas. 
Pada penderita diabetes, infeksi pada luka relatif sulit diatasi karena rusaknya pembuluh darah menuju lokasi luka ${ }^{8}$, hal ini terjadi akibat kadar glukosa darah tinggi dalam tubuh akibat diabetes, keadaan ini diperparah dengan adanya hipertensi, hyperlipidemia, dan kebiasaan merokok yang biasa disebut dengan penyakit arteri perifer (PAP). Adanya iskemik akibat insufisiensi arteri perifer menyebabkan terjadinya oksigenasi di daerah luka yang mempersulit penyembuhan ${ }^{9}$, karena antibiotik yang diberikan sebagai terapi oral, oksigen, zat makanan, perangkat kekebalan tubuh (sel darah putih, dll) sulit mencapai lokasi luka. Keadaan ini akan menghambat proses penyembuhan, membuat luka mengalami fase inflamasi yang memanjang $(\text { kronis })^{8}$. Jika keadaan ini tidak segera ditangani akan membahayakan jiwa penderita karena beresiko mengalami infeksi sistemik dan amputasi menjadi salah satu alternatif jalan keluar, selain itu akan menambah beban waktu dan biaya perawatan.

Terapi ozon bagging merupakan salah satu therapeutic devices atau terapi pelengkap dalam penatalaksanaan ulkus diabetikum ${ }^{10}$, karena memiliki efek terhadap penyembuhan luka, yakni melepaskan oksigen baru yang telah terbukti memiliki kemampuan bakterisidal dan merangsang enzim antioksidan $^{11}$. Pada bakteri, ozon mengganggu integritas kapsul sel bakteri melalui oksidasi fosfolipid dan lipoprotein. Ozon juga dapat berpenetrasi ke kapsul sel bakteri mempengaruhi secara langsung integritas cytoplasmic dan mengganggu beberapa tingkat kompleksitas metabolic ${ }^{10}$, sehingga dapat membunuh bakteri secara langsung.

\section{METODE PENELITIAN}

Penelitian eksperimental dengan rancangan pre test post test nonequivalent control group design. Subjek penelitian pada populasi dan sampel inifinit berjumlah 25 responden dengan ulkus diabetikum grade II fase inflamasi yang berkunjung ke Klinik Perawatan Luka "KITAMURA" Pontianak Indonesia dari November 2017 sampai dengan Maret 2018. Subjek penelitian terbagi menjadi 2 kelompok, yaitu kelompok kontrol berjumlah 11 responden dan kelompok intervensi berjumlah 14 responden. Kelompok kontrol mendapatkan perawatan luka dengan modern dressing yang bersifat antibakteri yaitu Calcium Alginat, Cutimed Sorbact, Aquacell, Dalethyne, dan Powder Iodosorp, sedangkan pada kelompok intervensi mendapat perawatan luka dengan modern dressing yang sama ditambah dengan terapi ozon bagging dengan konsentrasi 60$100 \mathrm{ug} / \mathrm{ml}$ selama 15 menit. Pengukuran koloni bakteri dan skor penyembuhan luka dilakukan setiap 3 hari sekali sampai hari ke 13. Koloni bakteri diukur dengan metode swab serta dihitung menggunakan kolonicounter. Koloni bakteri dengan hasil di atas $100 \mathrm{CFU} / \mathrm{ml}$ menunjukkan luka masih mengalami infeksi.

HASIL DAN PEMBAHASAN

Tabel 1. Distribusi Frekuensi Karakteristik Responden Pada Kelompok Kontrol dan Kelompok Intervensi

\begin{tabular}{|c|c|c|c|c|c|c|c|}
\hline \multirow[t]{2}{*}{ Karakteristik } & \multicolumn{2}{|c|}{$\begin{array}{c}\text { Kelompok } \\
\text { Kontrol }(n=11)\end{array}$} & \multicolumn{2}{|c|}{$\begin{array}{c}\text { Kelompok } \\
\text { Intervensi }(n=14)\end{array}$} & \multicolumn{2}{|c|}{ Total } & \multirow[t]{2}{*}{$p$} \\
\hline & $\mathrm{n}$ & $\%$ & $\mathrm{~N}$ & $\%$ & $\mathrm{n}$ & $\%$ & \\
\hline Usia(mean \pm SD) & \multicolumn{2}{|c|}{$58.55 \pm 7.090$} & \multicolumn{2}{|l|}{$61.50 \pm 9.338$} & \multirow{2}{*}{\multicolumn{2}{|c|}{$40-73$}} & \multirow[t]{2}{*}{0.461} \\
\hline Min-Max & \multicolumn{2}{|c|}{$49-69$} & \multicolumn{2}{|l|}{$40-73$} & & & \\
\hline Jenis Kelamin & & & & & & & 0.746 \\
\hline Laki-Laki & 6 & 54.5 & 7 & 50 & 13 & 52 & \\
\hline Perempuan & 5 & 45.5 & 7 & 50 & 12 & 48 & \\
\hline
\end{tabular}




\begin{tabular}{lccccccc}
\hline Kebiasaan Olahraga & & & & & & & 0.005 \\
Ya & - & - & 2 & 35.7 & 2 & 8 & \\
Tidak & 11 & 100 & 12 & 64.3 & 23 & 92 & \\
\hline Kebiasaan Merokok & 3 & 27.3 & 5 & 35.7 & 8 & 32 & 0.388 \\
Ya & 8 & 72.7 & 9 & 64.3 & 17 & 68 & \\
Tidak & $0.845 \pm 0.82$ & \multicolumn{7}{c}{$0.871 \pm 1.2$} & & 0.397 \\
\hline Nilai ABPI(mean+SD) & $0.7-1.0$ & $0.6-1.1$ & $0.6-1.1$ & \\
Min-Max & 1 & 9.1 & 3 & 21.4 & 4 & 16 & \\
Normal & 10 & 90.1 & 10 & 71.4 & 20 & 80 & \\
Oklusi Ringan & - & - & 1 & 7.1 & 1 & 4 & \\
Oklusi Sedang & & & & & & & \\
\hline
\end{tabular}

Didapatkan hasil bahwa baik pada kelompok kontrol maupun kelompok intervensi usia responden berada pada rentang umur lansia. Untuk jenis kelamin pada kelompok kontrol terdapat 6 $(54.5 \%)$ responden laki-laki dan 5 $(45.5 \%)$ responden perempuan, sedangkan pada kelompok intervensi responden laki-laki . dan perempuan masing-masing berjumlah 7 (50\%) responden. Sebagian besar responden tidak memiliki kebiasaan berolahraga (92\%) dan tidak merokok (68\%). Untuk nilai ABPI, diketahui $80 \%$ responden mengalami oklusi ringan (0.7-0.9).

Tabel 4. Analisis Perbedaan Jumlah Koloni Bakteri Antara Kelompok Kontrol dan Kelompok Intervensi

\begin{tabular}{|c|c|c|c|c|}
\hline \multicolumn{3}{|c|}{ Variabel } & \multirow[t]{2}{*}{ Selisih (IK95\%) } & \multirow[t]{2}{*}{$* \mathbf{P}$} \\
\hline $\begin{array}{l}\text { Jumlah } \\
\text { Koloni } \\
\text { Bakteri }\end{array}$ & Kelompok & Mean \pm SD & & \\
\hline \multirow[t]{2}{*}{ Pre Test } & Kontrol & $422.91 \pm 251.366$ & \multirow{2}{*}{$\begin{array}{l}-158.45(-387.932- \\
71.036)\end{array}$} & \multirow[t]{2}{*}{0.167} \\
\hline & Intervensi & $581.36 \pm 292.432$ & & \\
\hline \multirow[t]{2}{*}{ Post Test I } & Kontrol & $530.27 \pm 254.695$ & \multirow{2}{*}{$\begin{array}{c}-49.09(-246.896- \\
148.727\end{array}$} & \multirow[t]{2}{*}{0.613} \\
\hline & Intervensi & $579.36 \pm 223.055$ & & \\
\hline \multirow[t]{2}{*}{ Post Test II } & Kontrol & $562.55 \pm 193.091$ & \multirow[t]{2}{*}{$97.69(-45.507-240.884)$} & \multirow[t]{2}{*}{0.172} \\
\hline & Intervensi & $464.86 \pm 153.430$ & & \\
\hline \multirow[t]{2}{*}{ Post Test III } & Kontrol & $485.00 \pm 191.594$ & \multirow[t]{2}{*}{$68.29(-69.657-206.229)$} & \multirow[t]{2}{*}{0.316} \\
\hline & Intervensi & $416.71 \pm 142.209$ & & \\
\hline \multirow[t]{2}{*}{ Post Test IV } & Kontrol & $505.73 \pm 172.069$ & \multirow[t]{2}{*}{ 183.52(57.556-309.470) } & \multirow[t]{2}{*}{0.006} \\
\hline & Intervensi & $322.21 \pm 132.778$ & & \\
\hline
\end{tabular}

Uji general linear model $\mathrm{p}=0.125$. *Analisis post hoc.

Mean hasil pengukuran jumlah koloni bakteri dari pre test sampai post test IV masing-masing kelompok menunjukkan koloni bakteri masih berada pada jumlah di atas normal (>100 CFU/ml), Hasil multivariate test dikonfirmasi oleh hasil Parameter Estimates pada uji GLM, nilai p pada pengukuran post test IV yaitu di hari ke 13 didapat nilai $\mathrm{p}=0.006(\mathrm{p}<0.05)$ dan nilai interval kepercayaan (IK95\%) selisih rerata melewati nilai nol, sehingga disimpulkan mulai ada perbedaan signifikan jumlah koloni bakteri pada permukaan luka pasien ulkus diabetikum 
grade II antar kelompok pada hari 13. Walaupun jumlah koloni bakteri selam 13 hari masih berada di atas $100 \mathrm{CFU} / \mathrm{mg}$, namun antara kelompok kontrol dan

Tabel 5. Hasil Uji Beda Jumlah Koloni Bakteri Sebelum dan Sesudah Dilakukan Perawatan Luka Pada Kelompok Kontrol dan Kelompok Intervensi

\begin{tabular}{|c|c|c|c|c|c|c|c|}
\hline \multicolumn{4}{|c|}{ Kelompok Kontrol $(n=11)$} & \multicolumn{4}{|c|}{ Kelompok Intervensi $(n=14)$} \\
\hline $\begin{array}{l}\text { Penguku } \\
\text { ran }\end{array}$ & $\begin{array}{l}\text { Penguku } \\
\text { ran }\end{array}$ & $\begin{array}{c}\text { Mean } \\
\text { Perbedaan }\end{array}$ & $\begin{array}{c}p \\
\text { value }\end{array}$ & $\begin{array}{c}\text { Pengukur } \\
\text { an }\end{array}$ & $\begin{array}{l}\text { Pengukur } \\
\text { an }\end{array}$ & $\begin{array}{c}\text { Mean } \\
\text { Perbeda } \\
\text { an }\end{array}$ & $\begin{array}{c}p \\
\text { value }\end{array}$ \\
\hline Pre Test & Post IV & -82.818 & 1.000 & Pre Test & $\begin{array}{l}\text { Post Test } \\
\text { IV }\end{array}$ & 259.143 & 0.070 \\
\hline Pre Test & Post I & -107.364 & 1.000 & Pre Test & Post I & 2.000 & 1.000 \\
\hline $\begin{array}{l}\text { Post Test } \\
\text { I }\end{array}$ & Post II & -32.273 & 1.000 & Post I & $\begin{array}{l}\text { Post Test } \\
\text { II }\end{array}$ & 114.500 & 0.029 \\
\hline $\begin{array}{l}\text { Post Test } \\
\text { II }\end{array}$ & $\begin{array}{l}\text { Post Test } \\
\text { III }\end{array}$ & 77.545 & 1.000 & $\begin{array}{l}\text { Post Test } \\
\text { II }\end{array}$ & $\begin{array}{l}\text { Post Test } \\
\text { III }\end{array}$ & 48.143 & 0.518 \\
\hline $\begin{array}{l}\text { Post Test } \\
\text { III }\end{array}$ & $\begin{array}{l}\text { Post Test } \\
\text { IV }\end{array}$ & -20.727 & 1.000 & $\begin{array}{l}\text { Post Test } \\
\text { III }\end{array}$ & $\begin{array}{l}\text { Post Test } \\
\text { IV }\end{array}$ & 94.500 & 0.211 \\
\hline
\end{tabular}

Dari tabel di atas dapat dilihat bahwa pada kelompok kontrol dari pre test sampai post test $I V$ nilai $\mathrm{p}>0.05$ yang artinya tidak ada terjadi perubahan jumlah koloni bakteri yang signifikan. Sedangkan pada kelompok intervensi pada pengukuran post test I ke post test II nilai $\mathrm{p}<0.05$ yang artinya pada pengukuran hari keempat terjadi perubahan jumlah koloni bakteri yang signifikan .

\section{PEMBAHASAN}

a. Pengaruh Kombinasi Modern Dressing dan Terapi Ozon Bagging Terhadap Proses Penyembuhan Luka Pada Pasien Ulkus Diabetikum Grade II Fase Inflamasi

Hasil penelitian berdasarkan pengamatan selama 13 hari menunjukkan rata-rata skor BWAT pada kelompok kontrol dan kelompok intervensi yang terdiri dari 4 kategori berdasarkan ukuran luka yaitu pada ukuran luka $<4 \mathrm{~cm}^{2} \quad 31.00$ pada kelompok kontrol, hasil ini lebih tinggi dengan rata-rata skor BWAT pada intervensi jumlah koloni bakteri samasama mengalami penurunan. kelompok intervensi dengan ukuran yang sama yaitu 26.00. Sedangkan pada ukuran luka $4-<16 \mathrm{~cm}^{2}$ rata-rata skor BWAT pada kelompok kontrol yaitu 35.00 dan pada kelompok intervensi 34.00. Untuk ukuran luka $16-36 \mathrm{~cm}^{2}$ rata-rata skor BWAT pada kelompok kontrol 37.67 dan pada kelompok intervensi 36.00. Dan untuk ukuran luka $36-80 \mathrm{~cm}^{2}$ pada kelompok kontrol 40.00 sedangkan pada kelompok intervensi yaitu 42.00. Ulkus dikatakan mengalami proses penyembuhan jika mengalami proses fase inflamasi, fase proliferasi, dan fase maturasi. Proses penyembuhan luka tidak hanya terbatas pada proses regenerasi yang bersifat local, tetapi juga sangat dipengaruhi oleh faktor endogen (usia, status vaskularisasi, kondisi metabolic, imunologi, pemakaian obatobatan) ${ }^{7}$. Pada penelitian ini semua pasien mendapatkan terapi antibiotik Cefixime dan obat anti hiperglikemi untuk mengontrol kadar glukosa darah.

Penggantian balutan dilakukan sesuai dengan wound bed menggunakan konsep moist balance dan mengaplikasikan advance dressing 
(modern dressing). Perawatan luka dengan modern dressing harus tetap memperhatikan tiga tahap, yaitu mencuci luka, membuang jaringan mati, dan memilih balutan/dressing, selain itu juga harus mempertimbangan biaya yang dikeluarkan ${ }^{7,12}$.

Pemilihan balutan yang digunakan haruslah memiliki tujuan spesifik, tergantung pada jenis, tingkat keparahan, lokasi, dan posisi luka. Pada penelitian ini modern dressing yang digunakan yaitu dressing yang memiliki sifat antibakteri dan memiliki daya serap eksudat yang maksimal, yaitu seperti Aquacel Ag Foam Dressing, dressing ini memberikan aktivitas antimikroba spectrum luas secara terus-menerus selama masa pemakaian balutan. Pada studi in vitro, ionic silver aktif melawan berbagai strain bakteri yang resisten terhadap antibiotik termasuk methicillinresistant Stapilococcus aereus (MRSA) dan vancomycin-resistant Enterococcus (VRE), dressing ini juga mampu membunuh Pseudomonas aeruginosa dan berbagai bakteri aerob dan anaerob lainnya ${ }^{7}$. Dressing ini juga berfungsi sebagai absorban yang terbuat dari polyuthane dan memberikan tekanan pada permukaan luka. Indikasi penggunaan dari Ag Foam Dressing ini adalah luka dengan eksudasi sedang sampai berat, perlindungan profilaksis pada tulang yang menonjol atau area yang bersentuhan, luka dengan kedalaman sedang sampai keseluruhan, luka yang bergranulasi dan nekrosis, dan digunakan pada luka infeksi ${ }^{14}$.

Selain Aquacell, Calcium-Sodium Alginat Dressing digunakan dalam perawatan luka pada penelitian ini, dressing ini digunakan untuk jenis luka yang memiliki jaringan granulasi $>50 \%$ dengan produksi eksudat yang masih aktif. Dressing ini mampu menyerap eksudat luka secara efektif dengan cara ion natrium yang terkandung akan menarik air ke dalam serat kaltostat, membentuk jelly lembut dipermukaan luka, dan membantu autolysis debridement. Saat kontak dengan luka berdarah, kaltostat akan meningkatkan fungsi hemostatis, mengaktivasi koagulasi, dan agregat platelet. Indikasi penggunaan dressing ini adalah pada luka dengan eksudasi sangat banyak seperti luka yang menggaung, arterial ulcer, luka decubitus, tunneling, dan luka infeksi. Cutimed sorbact juga merupakan dressing yang digunakan dalam penelitian ini, mengingatkan luka yang dialami responden banyak yang memiliki tunneling yang merupakan sumber bakteri. Dengan dressing ini bakteri pada luka secara irreversible terikat pada dressing saat bersentuhan dengan serat hidrofobik Cutimed sorbact dalam lingkungan yang lembab, setelah bakteri terikat pada dressing, bakteri tidak akan lepas dari dressing ${ }^{7}$.

Modern dressing yang berbentuk powder seperti iodosorb beberapa kali digunakan, dressing ini merupakan serbuk steril yang berwarna coklat tua yang mengandung cadexomer (butiran mikro kanji yang dimodifikasi) yang berisi iodine $0.9 \%$, merupakan antiseptic yang aktif terhadap bakteri, jamur, dan virus, serta mampu menembus lapisan biofilm bakteri. Permukaan luka yang tertutup biofilm tidak akan mengalami proses penyembuhan luka yang baik, karena permukaannya tertutup bakteri sehingga pertumbuhan jaringan menjadi tidak maksimal ${ }^{7}$. Selain itu modern dressing dengan bahan aktif senyawa +dalethyne yang berasal dari olive oil yang diozonisasi juga digunakan, yang mampu membunuh bakteri MRSA ${ }^{15}$ dan membantu proses bakterisidal bakteri dan memiliki sifat antiinflamasi ${ }^{16}$. Berdasarkan analisis hasil pengukuran skor BWAT pada kelompok kontrol perubahan skor mulai terlihat signifikan pada post test ketiga yaitu di hari ke-10 $(\mathrm{p}<0.05)$, sedangkan skor pada saat pengukuran pre test ke pengukuran post test kedua masih belum menunjukkan perubahan nilai rata-rata skor BWAT 
$(\mathrm{p}>0.05)$. Penurunan signifikan pengukuran pada tiap item BWAT di kelompok kontrol yaitu terjadi pada skor tepi luka, tipe jaringan nekrotik, dan tipe eksudat.

Dilihat hasil akhir pada kelompok kontrol kategori luka $<4 \mathrm{~cm} 2$ mengalami penurunan skor 6 yaitu dari 31.00 menjadi 25.00. Pada kategori ukuran luka 4-<16 cm2 skor mengalami penurunan 5. Ukuran luka $16-36 \mathrm{~cm} 2$ mengalami penurunan skor sebesar 7.67 dari 37.67 menjadi 30.00. Dan pada ukuran luka 36-80 cm2 hanya mengalami penurunan skor 6. Semua luka mulai berada pada fase granulasi kecuali pada luka dengan ukuran 36-80 $\mathrm{cm}^{2}$ yang mana luka masih berada pada fase inflamasi. Untuk kategori berdasarkan dressing yang digunakan, luka dengan penggunaan dressing menggunakan Calcium-Alginat mengalami penurunan skor penyembuhan luka lebih banyak dibanding dressing yang lain yaitu skor awal 36.00 menjadi 29.67. Hasil ini berbeda dengan penelitian yang dilakukan oleh Yoland yang mendapatkan hasil penurunan skor nilai BWAT dari 40.00 menjadi 35.00 (effect size $=0.3$ ) pada penelitiannya yang menggunakan modern dressing jenis hidrokoloid pada perawatan ulkus diabetikum ${ }^{17}$.

Pada kelompok intervensi yang mendapat perawatan luka dengan modern dressing dan terapi ozon bagging mulai terjadi perubahan pengukuran pada post test kedua ( $\mathrm{p}=0.016)$. Kategori luka dengan ukuran $4-<16 \mathrm{~cm}^{2}$, yang digunakan modern dressing jenis Aquacell dan dikombinasikan dengan terapi ozon bagging banyak mengalami penurunan skor penyembuhan, yaitu dari skor awal 36.00 menjadi 26.00 menggambarkan luka mengalami perkembangan dan berada pada fase granulasi. Perubahan skor banyak terjadi pada item tipe jaringan nekrotik, jumlah jaringan nekrotik, tipe eksudat, jumlah eksudat, dan edema. Item-item tersebut merupakan item yang menunjukkan keadaan infeksi atau proses inflamasi pada luka, dengan berkurangnya skor tersebut, maka skor luka yang menggambarkan pertumbuhan granulasi dan epitelisasi juga menurun.

Keadaan luka grade II sangat beresiko terjadi proses infeksi yang lebih parah. Secara teori penyembuhan ulkus diabetikum grade II yang berada pada fase inflamasi membutuhkan waktu 4-10 hari untuk mencapai fase granulasi dengan keadaan glukosa darah yang normal dan stabil, keadaan vaskularisasi normal, dan tanpa infeksi. Namun apabila saat terjadi ulkus, keadaan glukosa darah relative tinggi, vaskularisasi tidak baik, dan dengan faktor penghambat berupa infeksi dan adanya penyakit penyerta, untuk mencapai fase granulasi membutuhkan waktu 4-21 hari bahkan lebih ${ }^{18}$.

Hasil pengukuran ABPI juga menggambarkan adanya gangguan vaskularisasi pembuluh darah. Dalam 13 hari observasi yang dilakukan luka mengalami regenerasi dan memulai fase granulasi, kecuali pada luka dengan ukuran awal $36-80 \mathrm{~cm}^{2}$ pada responden yang mengalami oklusi sedang.

Baik pada kelompok intervensi maupun kelompok kontrol infeksi menjadi penyulit atau faktor penghambat penyembuhan luka yang paling banyak. Kejadian infeksi dapat diidentifikasi dengan adanya tandatanda infeksi secara klinis diantaranya peningkatan suhu tubuh, peningkatan jumlah leukosit, proses inflamasi memanjang, cairan eksudat yang purulent, bau yang tidak sedap, serta hasil kultur lebih dari $10^{5}$ atau lebih dari 100 koloni bakteri per gram jaringan ${ }^{11}$.

Semua modern dressing yang digunakan memiliki sifat antibakteri, namun dilihat dari hasil pengukuran koloni bakteri pada kelompok intervensi menunjukkan penurunan yang cukup 
jauh dibandingkan hasil koloni bakteri di kelompok kontrol. Dan hasil analisis korelasi didapatkan hasil bahwa terdapat korelasi yang signifikan antara jumlah koloni bakteri dengan skor BWAT $(\mathrm{p}<0.05)$. Pada analisis nilai post hoc didapatkan hasil dari pengukuran pre test sampai post test IV pada kelompok kontrol tidak menunjukkan penurunan jumlah koloni bakteri yang signifikan $(\mathrm{p}=1.00)$ dan pada kelompok intervensi pada post test 1 ke post test II menunjukkan penurunan jumlah koloni bakteri yang signifikan $(\mathrm{p}<0.05)$. Hal ini dapat menjadi alasan mengapa penurunan skor BWAT pada kelompok kontrol yang tidak terlalu banyak dibanding kelompok intervensi. Tidak adanya perbedaan jumlah koloni bakteri antara kelompok kontrol dan kelompok intervensi dikarenakan pemilihan dressing yang tepat, dan dimungkinkan karena konsentrasi dan waktu pemberian terapi ozon bagging yang digunakan masih kurang optimal. Rosato menerangkan bahwa pada luka dengan kejadian lebih dari 1 kali, keadaan glukosa darah yang relative tinggi, dan pemberian antibiotik yang tidak spesifik, serta konsumsi lebih dari 14 hari dibutuhkan terapi ozon dengan konsentrasi 80-100 ug/dl dalam waktu 20 menit $^{19}$.

Pada kelompok intervensi, perawatan luka dilakukan selain dengan modern dressing, juga ditambah dengan terapi ozon bagging. Ozon merupakan oksidan yang jauh lebih kuat dibandingkan oksigen, sehingga dapat mengoksidasi banyak bahan yang tidak reaktif terhadap oksigen pada kondisi normal. Selain digunakan sebagai antiseptic, ozon juga dinyatakan memiliki efek antivirus, antijamur, dan antiprotozoa $^{20}$. Disamping itu ozon juga dapat memperbaiki distribusi oksigen dan pelepasan growth factor yang bermanfaat dalam mempercepat penyembuhan luka ${ }^{21}$.
Faktor infeksi sangat berhubungan dengan system imun tubuh. Seperti yang dikatakan oleh I Wayan bahwa ada korelasi positif yang kuat antara derajat keparahan ulkus diabetikum dengan presentase sel bermarkah $\mathrm{CD}^{+}$ pembawa malondialdehid sehingga pasien dengan ulkus diabetikum mudah terkena infeksi dan sulit untuk disembuhkan ${ }^{22}$. Hal ini terjadi karena keadaan hiperglikemi yang dialami oleh pasien DM, yang mana peningkatan glukosa ekstra seluler mengakibatkan terjadi reaksi glikasi (reaksi non enzimatik antara glukosa dengan protein) dan membentuk basa Schiff, kemudian menjadi produk amadori dan akhirnya membentuk protein yang sangat toksik yag disebut advanced glycation end product (AGEs) yang mana bila proses ini berlanjut akan mengakibatkan kematian $\operatorname{sel}^{22}$.

Hasil penelitian ini, menunjukkan bahwa ulkus diabetikum mempunyai respon inflamasi yang lebih lama, keadaan ini diperparah lagi dengan kadar glukosa darah yang tinggi, keadaan vaskularisasi ekstremitas bawah yang kurang baik, adanya penyakit penyerta, kebiasaan olahraga yang buruk yang mana keadaan ini menyebabkan suplai nutrisi dan zat aktif dari antibiotik yang membantu proses penyembuhan luka menjadi terhambat. Menunjukkan kesesuaian dengan teori dimana semakin lama sel-sel inflamasi berada pada lokasi ulkus maka akan menyebabkan kecenderung lebih lambatnya pembentukkan granulasi, hal ini juga sesuai dengan penelitian dari Werna yang menunjukkan bahwa terjadi perpanjangan fase inflamasi dengan peningkatan interleukin 1 (IL-1) dan interleukin 6 (IL-6) pada ulkus diabetikum sehingga memperlambat proses penyembuhan ${ }^{23}$.

Walaupun hasil penelitian ini tidak sejalan dengan hasil penelitian terdahulu yang mengatakan bahwa modern dressing dengan kombinasi terapi ozon 
lebih efektif dalam proses penyembuhan luka dibandingkan dengan modern dressing saja, namun pada penelitian ini terjadi penurunan jumlah koloni bakteri yang signifikan pada kelompok intervensi, yaitu pada post test pertama ke post test ke dua, ketiga, dan keempat $(\mathrm{p}<0.05)$. Pada kelompok intervensi di hari keempat jumlah koloni bakteri mulai mengalami penurunan, hal ini sesuai dengan teori yang mengatakan bahwa ozon mampu mengoksidasi berbagai jenis bakteri, spora, jamur, ragi, dan bahan organic lainnya ${ }^{19}$. Efek ozon terhadap bakteri adalah dengan mengganggu integritas kapsul sel bakteri melalui oksidasi fosfolipid dan lipoprotein, kemudian berpenetrasi ke dalam membrane sel, bereaksi dengan substansi sitoplasma dan merubah circulair plasmid DNA tertutup menjadi circulair plasmid DNA terbuka, yang dapat mengurangi efisiensi proliferasi bakteri, mempengaruhi secara langsung integritas cytoplasmic, dan mengganggu beberapa tingkat kompleksitas metabolic ${ }^{24}$. Disamping itu ozon juga dapat memperbaiki distribusi oksigen dan pelepasan growth factor yang bermanfaat dalam percepatan penyembuhan luka ${ }^{25}$.

Paparan oksigen yang tinggi dari ozon juga mempengaruhi proses hidroksilasi lisin dan prolin selama proses sintesis kolagen dan untuk penyatuan dan pematangan kolagen ${ }^{26}$. Selain itu pada kelompok intervensi terdapat penurunan skor pada item edema. Dibagian edema terdapat radikal bebas dalam jumlah yang besar. Daerah edema ini mengalami hipooksigenasi karena hipoperfusi. Peningkatan fibroblast akan mendorong terjadinya vasodilatasi pada daerah edema tersebut. Jadilah kondisi daerah luka tersebut menjadi hipervaskuler, hiperseluler, dan hiperoksia. Dengan pemaparan oksigen tekanan tinggi, terjadi peningkatan IFNy, i-NOS, dan VEGF. IFN-y ini menyebabkan TH-1 meningkat yang berpengaruh pada sel $\beta$ sehingga terjadi pengikatan Ig-G, dengan meningkatnya Ig-G maka efek fagositosis leukosit juga meningkat ${ }^{27,28}$.

Tidak adanya beda yang signifikan skor penyembuhan luka antar kelompok dikarenakan pemilihan balutan pada penggunaan modern dressing yang tepat. Pemilihan balutan adalah teknik dalam menciptakan lingkungan luka menjadi lembab, hal ini terdapat dalam manajemen perawatan luka (TIME). Hasil penelitian menunjukkan rerata penurunan skor penyembuhan luka lebih rendah dibandingkan dengan rerata penurunan skor luka pada penelitian Vonny baik pada kelompok yang diberikan kombinasi modern dressing dan terapi ozon bagging maupun kelompok dengan modern dressing. Selama 13 hari dengan 5 kali pengukuran jumlah koloni bakteri dan skor penyembuhan luka, walaupun untuk jumlah bakteri pada kedua kelompok berada di atas $100 \mathrm{CFU} / \mathrm{ml}$ namun selalu mengalami penurunan pada setiap kali pengukuran. Begitu halnya dengan skor penyembuhan luka, selama 13 hari penelitian dengan 5 kali pengukuran skor penyembuhan luka yang dilakukan setiap 3 hari sekali tidak menunjukkan hasil akhir luka sembuh, namun baik pada kelompok kontrol maupun kelompok intervensi samasama mengalami penurunan setiap kali pengukuran dan menggambarkan proses penyembuhan luka yang cukup baik, karena skor akhir luka di bawah 35.00 atau lebih rendah dibandingkan skor luka pada saat pre test, serta pada luka yang berada pada ukuran awal $<4 \mathrm{~cm}^{2}$, $4-<16 \mathrm{~cm}^{2}$, dan $16-36 \mathrm{~cm}^{2}$ mulai berada pada fase granulasi, sedangkan luka yang berada pada ukuran awal 36-80 $\mathrm{cm}^{2}$ masih berada pada fase inflamasi namun jumlah dan eksudat mengalami pengurangan skor. Berdasarkan tersebut maka perawatan luka dengan modern dressing dengan mempertahankan kondisi moist pada luka dengan 
pemilihan balutan atau dressing yang tepat sesuai dengan wound bed disertai dengan terapi ozon bagging sangat mungkin diterapkan untuk mempercepat proses penyembuhan ulkus diabetikum grade II yang berada pada fase inflamasi.

\section{SIMPULAN DAN SARAN}

Perawat harus memiliki pengetahuan cukup dalam penilaian luka untuk mendukung intervensi dalam penanganan luka yang mencakup promosi percepatan penyembuhan luka, mencegah infeksi, mencegah kerusakan kulit, mencegah perpanjangan rawat inap, meminimalkan ketidaknyamanan yang dialami pasien, meminimalkan beban keuangan pasien dan tempat kerja, serta meminimalkan beban waktu perawat. Tindakan perawatan luka dengan modern dressing dan terapi ozon bagging merupakan salah satu penatalaksanaan non farmakologis untuk pasien DM dengan komplikasi ulkus diabetikum, dapat menurunkan jumlah koloni bakteri dan mempercepat proses penyembuhan ulkus diabetikum grade II fase inflamasi. Intervensi dapat diterapkan dalam pemberian asuhan keperawatan pasien ulkus diabetikum. Keefektifan proses perawatan luka terletak dari kemampuan menilai dan mengobservasi keadaan luka, menentukan tindakan debridemen, kemampuan dalam memilih balutan, kemampuan mengkombinasikan dengan terapi komplementer salah satunya terapi ozon bagging dengan teknik, durasi, konsentrasi, dan keadaan yang tepat sesuai SOP.

\section{DAFTAR PUSTAKA}

1. Patricia Gonce Morton DF, Carolyn M. Hudak, Barbara M. Gallo. Keperawatan Kritis: Pendekatan Asuhan Holistik. Jakarta: EGC; 2011.

2. International Diabetes Federation. IDF Diabetes Atlas, Seventh edition2015.

3. Nicholas D. Barwell MCD, Brian Kennon, Helen E. Hopkinson, Claire
McDougall, Mattew J. Young, Hannah M.A. Robertson, Duncan Stang, Stephanie j. Dancer, Andrew Seaton, Graham P. Leese, on behalf of the Scottish Diabetes Foot Action Group. Diabetic Foot Infection: Antibiotic therapy and good practice recommendations. International Juurnal Of Clinical Practice. 2017.

4. Katrien T.B . Santema RMS, Mark J.W. Koelemay, Jim A. Reekers, Laura M.C. Van Dortmont, Arno OOmen, Luuk Smeets, Jan J. Wever, Dink A. Legemate, Dirk T. Ubbink. Hyperbaric Oxygen Therapy in The Treatment of Ischemic Lower Extremity Ulcers in Patient With Diabetes: Result Of The DAMO2CLES Multicenter Randomized Clinical Trial. Diabetes Care Journal. 2017.

5. American Diabetes Association. Standars Of Medical Care In Diabetes2017. The Journal of clinical and applied research and education. 2017;40(1):142.

6. PERKENI.

KONSENSUS, Pengelolaan Dan Pencegahan Diabetes Melitus Tipe 2 Di Indonesia 2015: PB. PERKENI; 2015.

7. Suriadi. Pengkajian Luka dan Penanganannya. Jakarta: Sagung Seto; 2015.

8. S. Eko Ch. Purnomo SUD, Kurniati Puji Lestari. Efektifitas Penyembuhan Luka MEnggunakan $\mathrm{NaCl}$ 0,9\% dan Hydrogel Pada Ulkus Diabetikum di RSU Kota Semarang. Prosiding Konferensi Nasional II PPNI Jawa Tengah. 2014.

9. Langi YA. Penatalaksanaan Ulkus Kaki Dabetes Secara Terpadu. Jurnal Biomedik 2011;3(2).

10. Borges GÁ, Elias ST, da Silva SMM, Magalhães PO, Macedo SB, Ribeiro APD, et al. In vitro evaluation of wound healing and antimicrobial potential of ozone therapy. Journal of Cranio-Maxillofacial Surgery. 2017;45(3):364-70. 
11. Jing Zhang MG, Cuihua Xie, Xiangdrong Luo, Qian Zhang, Yaoming Xue. Clinical Study: Increased Growth Factors Play a Role in Wound Healing Promoted By Noninvasive Oxygen-Ozone Therapy In Diabetic Patients With Foot Ulcers. Hindawi Publishing Corporation. 2014;2014(Oxidative Medicine and Cllular Longestive).

12. Maryunani A. Perawatan Luka mOdern Praktis Pada Wanita Dengan Luka Diabetes. Jakarta: TIM; 2013.

13. Vonny Nurmalya Megawati MNF. efektifitas modifikasi balutan modern dan terapi ozon terhadap penyembuhan ulkus diabetikum di WOCARE Clinic Bogor. Jurnal penelitian. 2016;2(1).

14. Handayani LT. Studi Meta Analisis Perawatan Luka Kaki Diabetes Dengan Modern Dressing. The Indonesian Journal Of Health Science. 2016;6(2).

15. Sayogo W. Potensit Dalethyne Terhadap Epitelisasi Luka pada Kulit Tikus yang Diinfeksi Bakteri MRSA. Biosains. 2017;19(1).

16. Ervina WF. Pengaruh Pemberian+ dalethyne Terhadap Jumlah Ekspresi IL-1 $\beta$ Pada Tikus yang Diinfeksi P. aeruginosa. Biosains. 2017;19(1).

17. Yoland. Modern Dressing pada Penyembuhan Ulkus Diabetikum. Junal Keperawatan. 2016;5(1).

18. Kowalak W, Mayer. Buku Ajar Patofisiologi. Jakarta: EGC; 2016.

19. Rosato ML, Schiaffino L, Luongo M, Mascolo L, Mattera S, Mainini M. Oxygen-ozone therapy effects on $\mathrm{PaO} 2$ value in a diabetic patient suffering from chronic peripheral obliterative arteriopathy. Ozone Therapy. 2016;1(1):21-2.

20. Bayer S, Kazancioglu HO, Acar AH, Demirtas N, Kandas NO. Comparison of laser and ozone treatments on oral mucositis in an experimental model. Lasers in medical science. 2017;32(3):673-7.

21. Franzini M, Valdenassi L, Ionita G. First evaluations of oxygen-ozone therapy in antibiotic-resistant infections. Ozone Therapy. 2016;1(1):5-7.

22. I Wayan Putu Sutirta Yasa KS, Anak Agung Gede Sudewa Djelantik, I Nyoman Mantik Astawa. Hubungan Positif Antara Ulkus Kaki iabetik Dengan Persentase Sel Bermarkah CD4+ Pembawa Malondialdehid. Bali: Udayana University; 2017.

23. Werna Nontji SH, Rosyidah Arafah. Teknik Perawatan Luka Modern dan Konvensional Terhadap Kadar Interleukin 1 dan Interleukin 6 Pada Pasien Luka Diabetik. Jurnal Ners. 2015;10(1).

24. Izadi M, Jafari NJ, Hosseini MS, Shafaat O. Therapeutic effects of ozone in patients with diabetic foot ulcers: review of the literature. Biomedical Research. 2017;28(18).

25. Zhang J, Guan M, Xie C, Luo X, Zhang $\mathrm{Q}$, Xue Y. Increased growth factors play a role in wound healing promoted by noninvasive oxygen-ozone therapy in diabetic patients with foot ulcers. Oxidative medicine and cellular longevity. 2014;2014.

26. Fedorko L, Bowen JM, Jones W, Oreopoulos G, Goeree R, Hopkins RB, et al. Hyperbaric oxygen therapy does not reduce indications for amputation in patients with diabetes with nonhealing ulcers of the lower limb: a prospective, double-blind, randomized controlled clinical trial. Diabetes Care. 2016;39(3):392-9.

27. Yücesoy T, Kütük N, Canpolat DG, Alkan A. Comparison of Ozone and Photo-Biomodulation Therapies on Mental Nerve Injury in Rats. Journal of Oral and Maxillofacial Surgery. 2017.

28. Akdeniz SS, Beyler E, Korkmaz Y, Yurtcu E, Ates U, Araz K, et al. The effects of ozone application on genotoxic damage and wound healing in bisphosphonate-applied human gingival fibroblast cells. Clinical oral investigations. 2017:1-7. 